\title{
Problem Dasar Kesenjangan Digital di Asia Tenggara
}

\author{
Ahmad Safril, Amalia Wardahni, \\ Della Febri Ponsela, M. Ahalla Tsauro \\ Departemen Hubungan Internasional Universitas Airlangga
}

\begin{abstract}
ABSTRAK
Sebagai sebuah kawasan yang terintegrasi, Asia Tenggara sesungguhnya tidak terkoneksi baik secara digital. Hal itu tampak dari lebarnya kesenjangan akses digital antara Singapura sebagai negara dengan perekonomian paling maju dengan negara-negara lainnya di kawasan ini. Akibatnya, komunikasi digital tidak dapat dijalankan secara lancar hingga berdampak pada interkonektivitas kawasan. Inilah problem yang diulas dalam artikel ini dan berdasarkan hasil riset yang telah dilakukan, ditemukan bahwa kesenjangan digital di Asia Tenggara disebabkan oleh kebijakan pemerintah yang tidak tepat sasaran dan rendahnya pendapatan per kapita sebagian besar masyarakat. Kebijakan pemerintah berkorelasi dengan kegagalan para pengambil kebijakan membangun jaringan infrastruktur telekomunikasi yang memadai dan merata di semua wilayah. Sementara, rendahnya pendapatan membuat masyarakat tidak mampu membeli perangkat teknologi seperti komputer dan telepon genggam sekaligus tidak memiliki modal cukup untuk berlangganan akses internet.
\end{abstract}

Kata Kunci: kesenjangan digital, kebijakan pemerintah, jaringan infrastruktur, pendapatan per kapita, biaya akses digital.

As an integrated region, Southeast Asia is not digitally connected. It is indicated by the level of digital divide between Singapore as the most developed country and other countries in this region. Consequently, digital communication still unable to work smoothly and affects regional interconnectivity. This is a problem explored in this article and based on the research, it is found that the problem is caused by inappropriate government policy and the low level of Gross Domestic Product (GDP) per capita of the most people in the region. Government policy is correlated to the failure of decision makers to build adequate and equal telecommunication infrastructure networks in all areas. Moreover, the low level of income has caused people unable to buying technology devices such as personal computer and smartphone, as well as subscribing internet access.

Key Words: digital divide, government policy, infrastructure networks, GDP per capita, the cost of digital access. 
Perkembangan pesat teknologi informasi dan komunikasi (TIK) tidak menjamin terciptanya kesetaraan akses bagi semua lapisan masyarakat di Asia Tenggara. Di tengah harapan terwujudnya sebuah komunitas Masyarakat Ekonomi ASEAN (MEA) yang terkoneksi secara utuh dalam sebuah kawasan terintegral, kesenjangan digital di Asia Tenggara justru tampak kentara antara satu negara dengan negara lain atau bahkan di dalam suatu negara. Menurut International Telecommunications Union (ITU 2008), di antara 300 juta orang yang terkoneksi internet di dunia, kurang dari satu persen tinggal di Asia Tenggara. Artinya, kawasan ini dapat dikatakan sebagai kawasan yang masih tertinggal secara digital.

Di Asia Tenggara, Singapura adalah negara yang memiliki akses internet paling canggih. Di kala 30 persen penduduk Singapura dapat menikmati akses internet dengan lancar, hanya terdapat 0,005 persen orang di Kamboja dan Vietnam yang terkoneksi dengan internet. Dalam observasi yang dilakukan penulis, akses internet di Singapura jauh lebih mudah didapatkan daripada di Kamboja dan Vietnam, bahkan di Indonesia dan Thailand. Secara global, Singapura menempati peringkat kedua (di bawah Swedia) Networked Readiness Index (NRI). Dalam NRI, posisi Singapura jauh di atas negara-negara Asia Tenggara lainnya seperti Malaysia (peringkat ke-29), Thailand (ke-77), Indonesia (ke-80), Vietnam (ke-83), dan Filipina (ke-86). Singapura memiliki indeks yang jauh lebih tinggi dibandingkan negara-negara lain di kawasan ini karena negara kota ini memiliki lingkungan politik dan regulasi yang kuat serta sangat kondusif untuk inovasi dan bisnis. NRI diukur berdasarkan 10 pilar: (1) lingkungan politik dan regulasi, (2) iklim bisnis dan inovasi, (3) infrastruktur digital, (4) keterjangkauan, (5) kemampuan dan keahlian, (6) penggunaan individu, (7) penggunaan bisnis, (8) penggunaan pemerintah, (9) dampak ekonomi, dan (10) dampak sosial. Berdasarkan parameter itu, Asia Pasifik -termasuk di dalamnya Asia Tenggaramerupakan kawasan yang dihuni tidak hanya negara-negara paling inovatif, paling makmur, dan paling terdigitalisasi, tetapi juga ditempati oleh negara-negara paling miskin dan lemah koneksi (Kwang 2012).

Dalam laporan lain yang dirilis oleh Lee Kuan Yew School of Public Policy (searchlightcatalysts.org 2016), dinyatakan bahwa tingkat akses internet di Asia sangat bervariasi antara yang paling kuat dan paling lemah. Di kawasan ini, jaringan, perlengkapan, dan harga akses internet sangat berbeda sehingga berdampak pada klasifikasi literasi digital. Negara-negara bertetangga belum tentu memiliki fakses internet setara. Meskipun wilayah Singapura dan Indonesia berbatasan, indeks NRI menampakkan kesenjangan digital yang sangat lebar di antara keduanya. Dibandingkan harga akses internet di Singapura yang hanya 6 dolar AS per Mbps, biaya sebesar 12 dolar AS per Mbps yang harus dikeluarkan penduduk Indonesia untuk mendapatkan akses internet tergolong mahal. Untuk tiap Mbps yang didapatkan, warga Singapura 
hanya perlu membayar 0,1 persen pendapatannya, sementara di Myanmar, orang harus mengeluarkan 182 persen pendapatannya

Sejumlah negara sesungguhnya telah memiliki rencana strategis dalam mengatasi problem kesenjangan digital. Thailand mengadopsi Bridging Digital Divide Strategic Plan (2008-2010) untuk melakukan penelitian dan pengembangan TIK, mengembangkan industri teknologi, dan mengembangkan teknologi nirkabel untuk memungkinkan daerahdaerah terpencil memiliki akses digital yang lebih baik. Malaysia memperkenalkan program penyediaan pelayanan program Internet Desa yang menargetkan penduduk pedesaan dan infrastruktur komputer untuk sekolah pedesaan. Singapura telah berkomitmen untuk menggelontorkan dana sebesar 25 juta USD untuk meningkatkan kualitas TIK. Namun, kondisi berbeda terjadi di Laos, Kamboja, dan Myanmar sebagai negara-negara dengan tingkat aksesibilitas paling rendah di Asia Tenggara. Di Kamboja, meskipun pemerintah telah mengadopsi kebijakan pendidikan TIK yang bertujuan meningkatkan akses terhadap pendidikan dasar melalui penggunaan teknologi (Richardson 2008), tetapi negara ini memiliki kelemahan regulasi yang menyediakan pondasi bagi persebaran pasar telekomunikasi. Di Myanmar, instabilitas negara mengakibatkan banyak proyek maupun investasi asing terhambat. Rendahnya kualitas sumber daya manusia dalam bidang TIK menyebabkan ketertinggalan rakyat Myanmar dari para imigran bertalenta dari negara-negara Asia Tenggara lainnya seperti Singapura (Digital Opportunity Forum 2005). Fenomena kesenjangan digital di Asia Tenggara merupakan indikasi perkembangan pesat TIK dua dekade terakhir tidak diiringi pemerataan akses untuk semua lapisan masyarakat. Kondisi tersebut memunculkan permasalahan terkait penyebab kesenjangan digital di kawasan ini.

\section{Faktor Penyebab Kesenjangan Digital}

Kesenjangan digital merupakan permasalahan perbedaan kesempatan akses informasi dan teknologi yang menciptakan kesenjangan akses antara individu, bisnis, dan bahkan wilayah geografi pada tingkatan sosial ekonomi yang berbeda. Hal itu akan memunculkan beragam pertanyaan seperti "Where does it occur and why? What are its causes? How is it to be measured? What are the relevant parameters? What is its extent, that is, how wide is the digital divide? Where is it most critical? What are its effects likely to be in the short term? In the longer term? What needs to be done to alleviate it?" (OECD 2001, 4-5).

Menurut OECD (2001, 5), indikator yang dapat digunakan untuk mengukur kuantitas kesenjangan digital adalah pendapatan, pendidikan, dan ketersediaan infrastruktur teknologi informasi dan 
komunikasi.Pendapatan menjadi variabel yang dapat menentukan seberapa kuat akses informasi didapat melalui usaha membayar layanan tersebut. Pendidikan menunjukkan bahwa pengetahuan juga penting untuk ditingkatkan sebagai kecakapan tersendiri untuk mendapatkan informasi. Sementara itu, jaringan infrastruktur telekomunikasi merupakan hal paling mendasar dalam masyarakat digital karena ketersediaannya menjadi syarat utama akses internet. Ketersediaan komputerisasi publik dalam suatu wilayah merupakan indikator kesiapan wilayah itu dalam memenuhi kebutuhan akses digital warganya. Suatu wilayah dinyatakan siap memenuhi akses digital jika fasilitas publik di dalamnya, seperti perpustakaan dan kantor instansi pemerintahan, mampu memberikan pelayanan digital secara memadai. Dalam hal ini, dengan jaringan infrastruktur yang memadai, negara maju cenderung lebih siap memasuki era digital daripada negara berkembang. Semakin maju perekonomian suatu negara, semakin mudah pemerintahnya mendanai proyek-proyek infrastruktur digital yang mampu menjamin interkoneksitas antarwarga. Sementara itu, kesenjangan digital dalam sektor domestik dapat dilihat dari dua variabel yakni pendapatan dan pendidikan.

Meski demikian, Paul Dimaggio, Eszter Hargittai, Coral Celeste, dan Steven Shafe (2001) memandang kesenjangan dapat terjadi tidak hanya disebabkan masalah ekonomi semata, tetapi juga tempat tinggal, status pekerjaan, pendapatan, edukasi, etnisitas, umur, gender, dan struktur keluarga. Pippa Norris (2001) menambahkan tiga konteks dalam kesenjangan digital, yakni kesenjangan global antara negara maju dan berkembang, kesenjangan sosial antara negara kaya informasi dengan negara miskin informasi, dan kesenjangan demokratis antara masyarakat yang dapat mengakses dan berpartisipasi dalam ruang publik dengan masyarakat yang terbatas dalam mengakses cyberspace.

Sejalan dengan Norris, Keniston dan Kumar (2003) menguraikan empat macam kesenjangan digital. Pertama, kesenjangan digital yang terjadi di seluruh dunia baik di negara berkembang atau negara maju yang dalam kesenjangan antara orang kaya, terpelajar dan berkuasa dengan mereka yang tidak kaya, kurang edukasi dan tidak memiliki kekuasaan. Kedua, kesenjangan yang terjadi akibat aspek bahasa dan budayakarena bahasa dan budaya tertentu ternyata memiliki tingkat aksesibilitas terhadap informasi yang lebih tinggi. Ketiga, kesenjangan yang berkaitan dengan semakin melebarnya ketimpangan antara negara kaya dengan negara miskin. Keempat, kesenjangan akibat munculnya kaum yang memiliki kemampuan dan tingkat edukasi cukup sehingga mereka menjadi pengendali teknologi dan informasi dalam masyarakat informasi, seperti pebisnis, ilmuwan dan konglomerat teknologi. Sementara itu, Neil Selwyn (2004) percaya bahwa akses, penggunaan, dan konsekuensi sebagai tiga indikator kesenjangan digital. Pendapat Selwyn diperkuat 
oleh pandangan James Valadez dan Richard Duran (2007) yang menyatakan kesenjangan digital tidak bisa hanya dipahami sebagai permasalahan fisik akses terhadap TIK, tetapi juga mencakup penggunaannya, bantuan dalam mengaksesnya, dan konsekuensi sosial yang diakibatkan olehnya.

Namun, argumen tersebut dibantah oleh Govindan Parayil $(2005,41)$ yang berpendapat kesenjangan digital tidak berkaitan dengan aksesibilitas, melainkan kesetaraan. Bagi Parayil, terlalu sederhana jika kesenjangan digital hanya dimaknai sebatas aksesibilitas. Sebab, lebih dari itu, menurut Parayil:

...the problems arising from these contradictory phenomena such as worsening income and wage gaps, uneven development, asymmetries in intraregional economic growth in parts of the developing world, and the deepening income inequalities in the developed world after the onset of the socalled informational economy and economic globalization are not unrelated or mutually exclusive developments.

Parayil meyakini permasalahan utama dalam perekonomian dunia adalah adanya kesenjangan antara orang kaya dan orang miskin, pemilik teknologi dan masyarakat yang tidak memiliki teknologi, serta masyarakat kaya informasi dan masyarakat miskin informasi. Kesenjangan digital bisa jadi berawal dari permasalahan akses teknologi, tetapi dampak sistemiknya merambat ke berbagai aspek kehidupan lainnya dan berpengaruh pada dimensi sosial, politik, ekonomi, hingga kultural. Parayil $(2005,48)$ menambahkan "It has been shown that the digital divide, income inequality, increasing returns, and other aspects of informational capitalism are not random or unconnected phenomena, but inseparable parts of it."

Senada dengan Parayil, Alec van Gelder (2006, 32) menyebut kesenjangan digital bukan hanya kondisi ekonomi yang timpang akibat ketidakmampuan akses teknologi informasi dan aset pengetahuan, tetapi juga sebagai bentuk ketimpangan perkembangan yang dirasakan oleh individu-individu yang tidak mendapatkan atau merasakan hasil nyata dari peningkatan pertumbuhan ekonomi negaranya. Gelder (2006, 31-32) menegaskan:

With this more comprehensive view of all of the genuinely important separators that divide rich and poor, the real 'digital divide' might better be defined as the 'development divide' between countries... Without the tools of the information economy and the infrastructure that supports them, however, some argue that the poor, who do not share the fruits of this considerable growth are held back by a so-called 'digital divide'. 
Kesenjangan digital merupakan efek globalisasi yang memperlihatkan disparitas penyebaran teknologi dan informasi antara negara maju dan negara berkembang. Proses globalisasi telah mendorong terciptanya TIK yang harapannya dapat dinikmati semua kalangan. Namun, faktanya, negara-negara miskin dan berkembang yang tidak mampu beradaptasi dengan TIK justru tertinggal di belakang negara-negara maju yang dengan mudah memanfaatkannya (Nwagwu 2006). Dalam catatan Mauro Guillen dan Sandra Suarez (2005, 681), di antara sekitar 6 miliar populasi dunia, hanya 10 persen di antaranya yang menggunakan internet. Mayoritas pengguna itu merupakan penduduk negara-negara maju, yakni sekitar 60 persen dari Singapura, Amerika Serikat, Korea Selatan, dan negara-negara Skandinavia. Sedangkan, kurang dari 1 persen pengguna internet berasal dari Afrika dan Asia Selatan.

Asia Tenggara yang dihuni oleh banyak negara berkembang merupakan kawasan yang tertinggal dari kawasan dengan akses internet canggih seperti Eropa. Menariknya, di kawasan ini, Singapura termasuk salah satu negara yang memiliki kapabilitas digital tertinggi di dunia. Fenomena itu terkonfirmasi melalui observasi lapangan yang dilakukan penulis di Indonesia, Thailand, Kamboja, Vietnam, dan Singapura. Berdasarkan analisis kualitatif (Silverman 2006) atas semua data yang ditemukan, baik data-data primer yang didapatkan di lapangan maupun data-data sekunder yang diperoleh dari berbagai sumber literatur (Silalahi 2006, 265-268), secara eksplanatif ditemukan penjelasan bahwa kondisi kesenjangan digital diAsia Tenggara disebabkan oleh duapersoalan. Pertama, kebijakan pemerintah yang tidak tepat sasaran sehingga gagal menyediakan jaringan infrastruktur yang mampu menyediakan kemudahan akses digital. Kedua, pendapatan per kapita yang rendah sehingga individu tidak memiliki dana cukup untuk membiayai akses digital.

\section{Kebijakan Pemerintah dan Jaringan Infrastruktur}

Di Asia Tenggara,kesenjangan digital terjadi akibattiga kebijakan pemerintah yang tidak tepat sasaran. Pertama, kebijakan pemerintah terkait penguasaan pasar telekomunikasi yang terdiri dari tiga tingkatan: (1) monopoli, (2) kompetisi sebagian, dan (3) kompetisi penuh. Kebijakan pemerintah dengan model penguasaan pasar monopoli berpotensi menciptakan kesenjangan yang lebih besar daripada penguasaan pasar secara kompetitif. Berkebalikan dengan pasar monopoli, model penguasaan pasar kompetitif mampu mengurangi kesenjangan karena adanya efektifitas kompetisi yang terjadi diantara para penyedia jasa layanan (Internet Service Provider, ISP) (OECD 2004). Melalui mekanisme ini, pemerintah dapat memberikan insentif kepada operator untuk melakukan bisnis mereka di daerah pedesaan 
dengan harapan akan bermanfaat untuk pemerataan akses informasi bagi penduduk pelosok yang biasanya jauh dari layanan teknologi informasi (Srinuan et al. 2010).

Dalam sistem pasartanpa kompetisi maupun regulasi, para konsumen, terutama di pedesaan, tidak merasakan keuntungan berupa bentuk penawaran yang beragam, harga yang lebih terjangkau, dan pilihan layanan yang memang lebih bagus. Berbanding terbalik dengan penguasaan monopoli, konsekuensi yang harus diambil adalah ketika sektor privat mendominasi sebuah pasar, investor akan lebih cenderung menarik apa yang diinvestasikan karena melihat pola konsumen yang tidak seantusias negara dengan model pasar kompetitif.

Mayoritas negara Asia Tenggara, yaitu Indonesia, Malaysia, Filipina, Singapura, dan Vietnam, memiliki pasar kompetisi penuh. Di antara kelima negara itu, Indonesia, Malaysia, Filipina, dan Singapura memiliki regulator independen. Di Indonesia, permintaan untuk akses internet meningkat seiring dengan kian terbukanya situasi politik yang mendorong semakin bermunculannya portal berita virtual. Dengan model pasar kompetisi penuh, perkembangan akses teknologi sangat minim intervensi pemerintah sehingga peran swasta menjadi dominan. Pada masa awal perkembangan teknologi informasi, kalangan swasta mengoperasikan warung internet yang dapat dinikmati masyarakat untuk mengakses media digital. Dalam tahapan perkembangan berikutnya, ketika telepon seluler canggih yang menawarkan aneka fitur marak digunakan masyarakat, muncul sejumlah layanan internet dengan menggunakan kartu dari berbagai perusahaan penyedia jasa seperti Telkomsel, XL, Indosat, dan lain sebagainya. Mereka menawarkan variasi tarif yang dapat dipilih sesuai kebutuhan konsumen.

Sebaliknya, di Myanmar yang menerapkan pasar monopoli, penikmat akses digital terkonsentrasi hanya di kota-kota besar dan jumlahnya cenderung lebih sedikit dibandingkan dengan mereka yang tidak mengaksesnya. Meskipun internet telah berkembang sejak 2000, kesenjangan digital tetapterjadi akibat kebijakan monopoli pemerintah yang membatasi dan mengontrol penuh akses internet (ASEAN \& Beyond 2012). Penerapan harga atas akses internet per jam membuat masyarakat berpendapatan rendah kesulitan mengakses. Dampaknya, pada 2010, pengguna internet di Myanmar tidak lebih dari 400.000 orang atau sekitar $0,8 \%$ dari populasi negara ini.Mayoritas penggunanyaterkonsentrasi di dua kota terbesar, Yangon dan Mandalay.

Kedua, kebijakan pemerintah dalam bekerjasama dengan ISP. Kerjasama semacam ini dimaksudkan untuk mengurangi biaya akses internet melalui investasi, baik dari ISP asing maupun lokal. Melalui 
kerjasama ini diupayakan tercipta interkoneksitas regional Asia Tenggara. Persoalannya, ketika bandwith internasional dirasa masih kurang, sebagian negara seperti Laos, Kamboja, dan Myanmarmenolak pasar kompetitif untuk ISP. Dalam perekonomian, harga merupakan daya tawar menarik bagi para ISP.Semakin kompetitif sebuah pasar, semakin bervariasi harga yang ditawarkan sehingga memungkinkan pula munculnya beragam inovasi layanan dari ISP. Ketika harga yang ditawarkan turun, maka permintaan akan semakin meningkat sehingga penawaran akan turun menanggapi respon atas jumlah permintaan dari konsumen (ISOC 2015).

Ketiga, kebijakan pemerintah terkait pemerataan akses TIK. Pemerataan akses digital sangat terkait dengan kondisi geografis dan jaringan infratruktur. Pemerintah di suatu negara dengan wilayah geografis luas memiliki tantangan besar dalam menjamin pemerataan akses digital.Semakin luas wilayah geografis, semakin kompleks pula problem infrastruktur yang dihadapi. Jaringan infrastruktur memadai merupakan syarat mutlak kemudahan akses digital yang berimplikasi pula pada peningkatan pertumbuhan ekonomi regional sebagai konsekuensi dari interkonektivitas yang diciptakannya. Negara-negara Asia Tenggara telah meliberalisasi industri infrastruktur dengan beberapa sektor yang lebih diregulasi daripada yang lain. Selain itu, beberapa negara juga telah melakukan privatisasi aset-aset infrastruktur yang berdampak pada kian bertambahnya jumlah sektor privat yang memiliki aset publik.

Menurut ASEAN Investment Report 2015, ketersediaan listrik yang memadai memberikan ruang tersendiri bagi setiap sektor publik untuk memaksimalkan penggunaan alat telekomunikasi sehingga mampu mendorong pertumbuhan TIK. Menurut United Nations Conference on Trade and Development (UNCTAD 2014), pada 2012 ada 78,5\% wilayah di Asia Tenggara yang teraliri listrik dan diproyeksikan meningkat hingga $88,1 \%$ pada 2020. Persoalannya, muncul ketimpangan jika membandingkan antarnegara. Singapura, Malaysia, dan Brunei Darussalam kini telah memiliki ketersediaan listrik 100\% merata di seluruh wilayahnya. Sementara, banyak negara lain seperti Indonesia dan Filipina diperkirakan baru memiliki wilayah yang teraliri listrik sepenuhnya pada 2030. Yang paling parah, dalam kondisi sekarang, Myanmar memiliki ketersediaan listrik hanya 32\%. Kondisi kian parah terlihat di pelosok, atau bahkan di daerah perbatasan. Di perbatasan Kamboja dan Vietnam misalnya, jalan raya yang menghubungkan kedua negara itu tidak selalu diterangi oleh lampu-lampu yang energinya digerakkan oleh listrik. Tidak meratanya sumber daya listrik yang ada di Asia Tenggarayang lantas disikapi dengan kebijakan pemerintah yang timpang menjadi hambatan tersendiri bagi pertumbuhan infrastruktur telekomunikasi. 
Di Malaysia, investasi pemerintah lebih terfokus di Kuala Lumpur daripada kota-kota lainnya. Pada masa awal perkembangan TIK, sejak 1993 hingga krisis ekonomi melanda pada 1998,terjadi peningkatan disparitas antara ibukota dan kota-kota lainnya. Meskipun total investasi di sektor telekomunikasi naik dari o,73\% PDB tahun 1987-1991 menjadi 1,52\% di tahun 1992-1995, namun peningkatan terbesar terjadi di Kuala Lumpur,mencapai 30\% pada 1998. Tren selanjutnya menampakkan peningkatan serupa hingga kini. Hal itu semakin melebarkan tingkat kesenjangan antara ibukota dan kota-kota lainnya. Konsentrasi pembangunan TIK di wilayah Kuala Lumpur semakin memudahkan masyarakat ibukota untuk menikmati kualitas pelayanan internet secara maksimal, kondisi yang tidak ditemukan di daerahdaerah pedesaan. Dengan demikian, secara tidak langsung sebuah kesenjangan digital telah tercipta karena disparitas tingkat investasi di produk telekomunikasi dan jasa antara ibukota dan daerah-daerah lainnya di Malaysia.

Di Myanmar, jaringan infrastruktur telepon dan internet tidak dapat memenuhi meningkatnya permintaan. Dalam kondisi demikian,proyekproyek pengembangan infrastruktur TIK diharapkan akan meningkatkan efisiensi melalui e-government dan menyempitkan kesenjangan digital. Namun, situasi yang tidak stabil telah memperlambat kemajuan proyek pengembangan infrastruktur TIK yang tampak dari lenyapnya potensi investasi asing dan melambatnyadukungan kerjasama internasional. Selain itu, kurangnya anggaran serta mahalnya harga listrik dan bahan bakar juga menjadi persoalan tersendiri. Upaya mengatasinya dengan membangun lembaga pengembangan TIK, Myanmar Computer Federation (MCF), pada 1998, juga belum membuahkan hasil meskipun lembaga ini telah membuka pusat akses publik di seluruh wilayah negara (The Internet Society 2015).

Kondisi semacam itu tidak ditemukan di Singapura yang memiliki luas wilayah paling kecil di antara semua negara Asia Tenggara. Sebagai negara kecil dengan sumber daya alam terbatas, Singapura harus bergantung pada pengetahuan sebagai aset utama pengembangan. Menyadari hal itu, sejak awal perkembangan TIK, pemerintah Singapura telah meluncurkan kebijakan untuk mengurangi kesenjangan digital dengan mengembangkan ekonomi berbasis pengetahuan pada 1992. Singapura ditopang oleh industri TIKyang menyumbang lebih dari USD 70 miliar dalam pertumbuhan ekonomi negara. Industri sektor telekomunikasi ini diatur oleh Singapore Infocomm Development Authority (IDA) yang bertanggung jawab dalam perencanaan dan pengembangan infrastruktur TIK. Dalam melakukannya, IDA memupuk industri TIK yang bersemangat dan kompetitif di Singapura, salah satunya dengan menarik investasi asing dan menopang pertumbuhan 
PDB jangka panjang melalui pengembangan teknologi inovatif. Selain itu,pemerintah Singapura memprivatisasi Singapura Telecommunication Limited (SingTel) agar perusahaan ini lebih leluasa membangun infrastruktur. Pemerintah Singapura percaya privatisasi ituakan menghemat biaya melalui standardisasi dan berbagi komputasi sumber daya.Karena itu, Singapura kini memiliki infrastruktur TIK yang berkembang dengan sangat baik (Evers, 2013).

\section{Pendapatan Per Kapita dan Biaya Akses Digital}

Tidak dapat dipungkiri,modal sangat diperlukan untuk mendapatkan akses digital. Karena masyarakat yang memiliki pendapatan tinggi lebih mampu membiayai pengeluaran untuk akses digital daripada masyarakat dengan pendapatan rendah, maka kesenjangan pendapatan dapat berimplikasi pada kesenjangan digital. Kesenjangan pendapatan adalah perbedaan dalam pendapatan yang dihitung dari rata-rata gross domestic product (GDP) per kapita dan tingkat kemiskinan. Di antara semua negara, kesenjangan pendapatan terlihat antara negara-negara ASEAN-6 (Singapura, Malaysia, Thailand, Indonesia, Filipina dan Brunei Darussalam) yang memiliki tingkat pendapatan per kapita tertinggi dan CLMV (Kamboja, Laos, Myanmar dan Vietnam)dengan pendapatan per kapita terendah (Alavi \& Ramadan 2008). Berdasarkan laporan yang dirilis Bank Dunia pada 2015 (Tabel 1), Singapura memiliki GDP per kapita tertinggisebesar US\$52.888, sangat timpang dengan GDP per kapita Kamboja yang hanya US\$ 1.158. Artinya, Asia Tenggara diliputi kesenjangan signifikan yang tampak melalui lebarnya jarak jumlah pendapatan antara Singapura dan Brunei Darussalam yang mencapai angka puluhan ribu dolar AS dengan delapan negara lainnya yang tidak melebihi US\$10.000.

Kesenjangan pendapatan per kapita berkorelasi dengan kesenjangan digital karena untuk mendapatkan akses internet, masyarakat membutuhkan uang untuk membeli peralatan teknologi seperti komputer dan telepon seluler sekaligus berlangganan kuota internet dan wifi. Meskipun wifi kadangkala bisa didapat secara gratis, tetapi di sejumlah wilayah yang tidak memiliki infrastruktur memadai, masyarakat perlu mengeluarkan uang untuk membeli pulsa guna berlangganan kuota internet. Dalam masyarakat digital, pulsa tidak lagi berguna untuk menelepon maupun mengirim pesan singkat, namun juga untuk menikmati dunia maya yang penuh informasi. 


\section{Tabel 1. GDP Per Kapita Asia Tenggara Tahun 2015 (dalam US\$)}

\begin{tabular}{clc}
\hline No. & \multicolumn{1}{c}{ Negara } & GDP Per Kapita \\
\hline 1. & Singapura & 52.888 \\
\hline 2. & Brunei Darussalam & 36.607 \\
\hline 3. & Malaysia & 9.766 \\
\hline 4. & Thailand & 5.816 \\
\hline 5. & Indonesia & 3.346 \\
\hline 6. & Filipina & 2.899 \\
\hline 7. & Vietnam & 2.111 \\
\hline 8. & Laos & 1.812 \\
\hline 9. & Myanmar & 1.203 \\
\hline 10. & Kamboja & 1.158 \\
\hline
\end{tabular}

Sumber: World Bank 2015.

Kebutuhan modal inilah yang secara linier turut mendeterminasi kemampuan seseorang untuk mendapatkan akses digital dengan mempertimbangkan pendapatannya. Tingkat pendapatan per kapita dapat menentukan prioritas kebutuhan individu. Bagi masyarakat yang memiliki pendapatan tinggi, bukan perkara sulit bagi mereka untuk mendapatkan akses digital, apalagi jika hal itu telah menjadi kebutuhan prioritas. Namun, bagi masyarakat yang memiliki pendapatan rendah, mereka lebih memprioritaskan memenuhi kebutuhan sandang, pangan dan papan terlebih dahulu. Karena itu, warga negara Singapura dan Brunei Darussalam dapat memenuhi kebutuhan akses digital lebih mudah dengan uang yang mereka miliki. Sementara, bagi warga negaranegara CLMV yang memiliki pendapatan per kapita antara US\$1.00o dan US\$2.00o, akses digital tidak saja mudah didapat.

Indikator atas realita tersebut dapat dilihat dari kepemilikan komputer pribadi dan beban biaya berlangganan internet. Pada 2005, ASEAN One merilis data mengenai tingkat pertumbuhan rata-rata penetrasi TIK di Asia Tenggaraberdasarkan empat aspek: (1) fixed lines, (2)mobile phone, (3) pengguna internet, dan (4) kepemilikan komputer. Mengacu pada data itu, fixed lines rata-rata negara-negara di Asia Tenggara mencapai $3,92 \%$, kepemilikan mobile phone mencapai $41,12 \%$, pengguna internet mencapai $3,15 \%$ dan kepemilikan komputer mencapai 9,83\%. Realita yang tergambar dalam data itu memperlihatkan tingkat kepemilikan computer berbanding lurus dengan tingkat pengguna internet, yakni Singapura sebagai pemilik komputer terbanyak, juga sebagai pengguna internet terbanyak. Sebaliknya, Kamboja dan Myanmar menunjukkan tingkat kepemilikan dan pengguna internet yang rendah.Perihal kepemilikan komputer, Singapura menunjukkan tingkat kepemilikan 
yang paling banyak yakni 62,2 pemilik per 100 orang; diikuti oleh Malaysia, Brunei Darussalam, Thailand, Filipina, Indonesia, Vietnam, Myanmar, dan Laos. Kamboja menempati urutan terakhir dengan jumlah pemilik komputer sebanyak 0,2 dari 100 orang. Sementara, dari aspek pengguna internet, Singapura tetaplah yang tertinggi dengan jumlah 5.043 pengguna per 10.000 orang. Myanmar merupakan negara pengguna internet terendah dengan hanya 5,64 pengguna dari 10.000 orang (ASEAN One 2005).

\section{Tabel 2. Biaya Langganan Internet Non-Mobile Per Bulan}

\begin{tabular}{ll}
\hline \multicolumn{1}{c}{ Negara } & \multicolumn{1}{c}{ Biaya per Bulan (USD) } \\
\hline Kamboja & $\$ 100$ per Mbps \\
Indonesia & From $>$ \$100 to $\$ 60 / 70$ per Mbps \\
Laos & $\$ 100$ per Mbps \\
Malaysia & $\$ 25-30$ per Mbps bought in volume \\
Myanmar & $>\$ 100$ per Mbps \\
Filipina & $\$ 80$ per Mbps \\
Singapura & $<\$ 10$ per Mbps bought in volume \\
Thailand & $\$ 80$ per Mbps \\
Vietnam & $\$ 70$ per Mbps \\
\hline & \multicolumn{1}{c}{ Sumber: UNESCAP 2016 }
\end{tabular}

Terkait beban biaya berlangganan internet, harga di negara-negara Asia Tenggara amat bervariasi. United Nations Economics and Social Commission for Asia and the Pacific (UNESCAP 2016) menyebutkan bahwa wilayah yang memiliki konektivitas kabel di bawah laut seperti Singapura menikmati harga kompetitif dari kuota internet kurang dari US \$10 per Mbps. Sementara, negara lain yang kurang memiliki koneksi seperti Laos, Kamboja, dan Myanmar, harus membayar setidaknya US $\$ 100$ US per Mbps (Tabel 2). Jika dibandingkan, tarif berlangganan kuota internet mobile lebih murah daripada non-mobile.Pada 2016, Tech In Asiamerilis data kompilasi biaya 1 GB mobile data dari masingmasing negara di Asia Tenggara dengan mengalkulasi upah minimum dan jam kerja yang dibutuhkan untuk memenuhinya (Tabel 3). Hasilnya, meskipun Singapura dan Brunei Darussalam memiliki biaya terbesar, yakni sekitar US\$7, tetapi besarnya upah minimum yang dimiliki membuat masyarakat hanya membutuhkan waktu kurang dari dua jam kerja untuk dapat membeli biaya paket mobile data tersebut. Hal ini berbeda dengan Vietnam yang membutuhkan 6 jam kerja untuk dapat 
membeli paket data serta Myanmar yang membutuhkan 8 jam kerja hanya untuk bisa membeli paket mobile data sebesar 1 GB (Tech in Asia, 20 Januari 2016). Dengan kata lain, untuk membeli 1 GB mobile data, masyarakat Myanmar harus bekerja dalam satu hari, dengan perhitungan 8 jam kerja per harinya. Besarnya tarif berlangganan internet inilah yang kemudian memicu masyarakat mencari tempat yang menyediakan wifi secara gratis seperti taman restoran, kafe, dan fasilitas-fasilitas publik.

Tabel 3. Biaya Langganan Internet Mobile Per Bulan

\begin{tabular}{llll}
\hline \multicolumn{1}{c}{ Negara } & \multicolumn{1}{c}{$\begin{array}{c}\text { Biaya 1 GB } \\
\text { Mobile Data } \\
\text { (US\$) }\end{array}$} & $\begin{array}{c}\text { Upah } \\
\text { Minimum } \\
\text { (US\$) }\end{array}$ & Jam \\
\hline Brunei & 7.09 & $5 \cdot 76$ & $1: 04$ \\
Darussalam & & & \\
Singapura & 7.11 & 4.03 & $1: 46$ \\
Kamboja & 1.50 & 0.66 & $2: 16$ \\
Thailand & 3.29 & 1.15 & $2: 51$ \\
Malaysia & 4.56 & 1.18 & $3: 51$ \\
Laos & 4.11 & 0.84 & $4: 53$ \\
Indonesia & 2.84 & 0.54 & $5: 16$ \\
Filipina & 3.71 & 0.69 & $5: 22$ \\
Vietnam & 3.58 & 0.59 & $6: 04$ \\
Myanmar & 3.68 & 0.46 & 8 \\
\hline
\end{tabular}

Sumber: Tech In Asia 2016

Jika diklasifikasikan menurut pendapatan per kapita tertinggi, menengah, dan terendah, maka dihasilkan temuan berikut. Pertama, sebagai masyarakat dengan pendapatan per kapita tertinggi, yakni US\$52.888, bukan perkara sulit bagi orang Singapura untuk mendapatkan telepon seluler canggih dengan harga termahal sekalipun. Ditambah dengan dengan tarif kuota internet yang sangat murah dibandingkan negara-negara lainnya, yakni kurang dari US\$10, tidak mengherankan apabila orang Singapura mampu menikmati akses digital dengan mudah dan tanpa hambatan apapun. Kedua, sebagai masyarakat dengan pendapatan per kapita menengah, yakni US\$3.346,orang Indonesia memang masih dapat menjangkau akses digital. Telepon seluler canggih dengan berbagai fitur memang dapat terbeli, tetapi biaya berlangganan internet yang cenderung terus meningkat membuat akses internet semakin sulit dijangkau. Apalagi, pemberlakuan tarif yang berbeda secara signifikan antarzona wilayah seperti di Jawa dan Papua menyebabkan terjadinya disparitas akses digital antara satu masyarakat dengan masyarakat lainnya dalam internal negara. Tarif internet di Papua yang mencapai 20 kali lipat dibandingkan di Jawa membuat masyarakat Papua harus mengeluarkan biaya ekstra daripada 
masyarakat Jawa (Liputan 6, 15 Januari 2014). Ketiga, sebagai masyarakat dengan pendapatan per kapita terendah, yakni US\$1.203, rata-rataorangMyanmar tidak mampu membeli telepon seluler canggih dan berlangganan internet.Kecuali oleh orang-orang yang memiliki kekayaan lebih, akses digital sulit dijangkau oleh kebanyakan masyarakat Myanmar karena biaya yang dibutuhkan untuk memperolehnya melebihi pendapatan per kapita mereka.

\section{Simpulan}

Berdasarkan temuan pembahasan pada bagian sebelumnya, dapat ditarik empat kesimpulan terkait penyebab kesenjangan digital di Asia Tenggara.Pertama, perbedaan sistem pasar yang dianut tiap negara di Asia Tenggara, antara monopoli, kompetisi sebagian, dan kompetisi penuh, berdampak terhadap interkonektivitas antarnegara dalam satu kawasan. Keberhasilan Singapura dan Malaysia dalam memeratakan akses digital dengan berlandaskan sistem pasar kompetitif yang dijalankan tidak diiringi oleh keberhasilan negara-negara lainnya. Model penguasaan pasar semacam itu amat terkait dengan kebijakan yang diambil pemerintah. Apabila pemerintah berhasil menerapkan model penguasaan pasar secara kompetitif, hal itu akan dapat mengurangi kesenjangan digital karena adanya efektifitas kompetisi yang terjadi di antara para penyedia jasa layanan internet.

Kedua, jaringan infrastruktur yang hanya terkonsentrasi di pusat kota berdampak pada melemahnya jaringan di daerah pinggiran sehingga menyulitkan akses komunikasi dan informasi antarwilayah. Sebagai negara kota, Singapura memiliki jaringan infrastruktur sangat canggih yang nyaris tanpa hambatan akses. Kondisi itu berbeda dengan Indonesia yang memiliki wilayah sangat luas dengan sebagian di antaranya dikelilingi oleh pegunungan yang menghambat pembangunan infrastruktur. Ada tantangan besar untuk memperkuat infrastruktur secara merata karena hal itu terkait dengan biaya yang sulit dijangkau. Mahalnya biaya itu pula yang dirasa memberatkan penduduk berpendapatan rendah.

Ketiga, karena mengakses informasi membutuhkan modal, sementara tingkat pendapatan per kapita di Asia Tenggara berbeda, maka masyarakat menengah ke bawah seringkali tidak terkoneksi secara digital dibandingkan mereka yang kaya. Masyarakat berpendapatan tinggi seperti di Singapura dan Brunei Darussalam dapat memenuhi kebutuhan akses digital lebih mudah dengan uang yang mereka miliki. Sementara, bagi masyarakat berpenghasilan rendah di negara-negara CLMV, akses digital tidak mudah didapat. Dengan pendapatan rendah, mereka lebih mementingkan kebutuhan primernya yang tercukupi 
daripada memprioritaskan akses informasi yang tidak mereka butuhkan dalam hidup. Kondisi inilah yang membuat interkonektivitas antarlapisan masyarakat menjadi lemah hingga menciptakan kesenjangan digital di Asia Tenggara.

Keempat, permasalahan kesenjangan digital meningkat seiring dengan adanya pendapatan yang kian rendah, jarak upah yang melebar, perkembangan yang tidak setara, serta terciptanya kondisi asimetris di dalam pertumbuhan ekonomi intra kawasan. Meskipun satu dekade terakhir negara-negara di Asia Tenggara mengalami pertumbuhan ekonomi signifikan, tetapi pertumbuhan tersebut tidak mampu menyaingi Singapura sebagai negara maju. Tampak ketimpangan yang lebar antara perekonomian Singapura dengan sembilan negara lainnya. Hal itu berbanding lurus dengan lebarnya kesenjangan digital antara Singapura dengan negara-negara lain. Di era digital, ketika kebutuhan akses internet masyarakat Singapura tercukupi, masyarakat di negaranegara lain seperti Myanmar dan Kamboja masih harus memikirkan kebutuhan primernya terkait sandang, pangan, dan papan. Dalam kondisi demikian, tidak semua masyarakat di Asia Tenggara memiliki aksesibilitas sama untuk menikmati dunia digital karena masih banyak di antaranya yang berada dalam lingkaran kemiskinan dengan pendapatan yang rendah. Kebutuhan akses digital bukanlah prioritas bagi mereka seperti halnyamasyarakat berpendapatan tinggi yang dapat dengan mudah mendapatkannya.

\section{Daftar Pustaka}

\section{Buku dan Artikel dalam Buku}

Evers, Gerke, 2013. Local Knowledge and Digital Divide: Focus on Southeast Asia. Bandar Seri Begawan: Institute of Asian Studies, Universiti Brunei Darussalam.

Keniston, Kenneth dan Deepak Kumar, 2003. The Four Digital Divides.New Delhi: Sage Publications.

Norris, Pippa, 2001. Digital Divide: Civic Engagement, Information Poverty, and the Internet Worldwide. Cambridge: Cambridge University Press.

Silalahi, Ulber, 2006. Metode Penelitian Sosial. Bandung: Unpar Press. Silverman, David, 2006. Interpreting Qualitative Data. London: SAGE. Srinuan, C.et al., 2010. "Digital Divide in ASEAN Countries: Explaining the Gap," dalam P. Gugler dan J. Chaisse (eds.), 2010.Competitiveness of ASEAN Countries: Corporate and 
Regulatory Drivers, New Horizons in International Business. London: Edward Elgar, hlm. 153-162.

\section{Jurnal}

Alavi, Rokiah dan Aisha Al-Alim Ramadan, 2008. "Narrowing Development Gaps in ASEAN," Journal of Economic Cooperation, 29 (1): 29-60.

Nwagwu, Williams Ezinwa, 2006. "Integrating ICTS into the Globalization $\mathrm{f}$ the PoorDeveloping Countries," International Development, 22 (3): 167-179.

Parayil, Govindan, 2005. "The Digital Divide and Increasing Returns: Contradiction of Informational Capitalism," The Information Society, 21: 41-51.

Richardson, Jayson W., 2008. "ICT in Education Reform in Cambodia: Problems, Politics and Policies Impacting Implementation," Information Technologies and International Development, 4(4): 6782.

van Gelder, Alec, 2006. "Fashion and Foreign Aid: A Realistic Look at the 'Digital Divide,", Review-Institute of Public Affairs, 58 (1): 31-34.

Selwyn, Neil, 2004. "Reconsidering Political and Popular Understandings of the Digital Divide,"New Media \& Society, 6 (3): 341-362.

Valadez, James R. dan Richard Duran, 2007. "Redefining the Digital Divide: Beyond Access to Computers and the Internet," The High School Journal, 90 (3): 31-44.

Guillen, Mauro F. dan Sandra L. Suárez, 2005. "Explaining the Global Digital Divide: Economic, Political and Sociological Drivers of CrossNational Internet Use," Social Forces, 84(2): 681-708.

\section{Laporan}

Dimaggio, Paul etal., 2001. "From Unequal Access to Differentiated Use: A Literature Review and Agenda for Research on Digital Inequality," Laporan Penelitian untuk the Russell Sage Foundation.

OECD, 2001. Understanding Digital Divide. Paris: OECD Publication.

Divide"

, 2004."Regulatory Reform as a Tool for Bridging the Digital

[online].https://www.oecd.org/sti/ieconomy/34487084.pdf(diakses 25 Maret 2016).

World Bank, 2015. "GDP per Capita” [online]. http://data.worldbank.org/indicator/NY.GDP.PCAP.CD?end=2015\& start=1960\&view=chart (diakses 26 Februari 2016). 
UNCTAD, 2014. Progress Made in the Implementation of and Followup to the Outcomes of the World Summit on the Information Society at the Regional and International Levels. New York: UNCTAD.

UNESCAP, 2016. State of ICT in Asia and the Pacific 2016: Uncovering the Widening Broadband Divide. Bangkok: UNESCAP.

\section{Artikel Online}

Anonim, t.t. “Asia's Digital Divide" [online]. http://www.searchlightcatalysts.org/node/768/Tools(diakses 11 Maret 2016).

ASEAN One, 2005. "Towards Closer Economic Integration: Is the ASEAN Digital Divide Shrinking?” [online]. http://www.asean.org/uploads/archive/article254.pdf (diakses 29 Maret 2016).

ASEAN \& Beyond, 2012. "Many Areas Don't Have Power, Internet Access, Most Users in Big Cities" [online].http://www.nationmultimedia.com/asean\&beyon/digitaldivide-between-urban-rural-areas-30186875.html (diakses 29 Maret 2016).

Liputan 6, 2014. "Tarif Internet di Papua Lebih Mahal 20 Kali Lipat dari Jawa" 15 Januari [online].http://bisnis.liputan6.com/read/80o607/tarif-internet-dipapua-lebih-mahal-20-kali-lipat-dari-jawa (diakses 27 Maret 2016).

Digital Opportunity Forum, 2005. "Informatization Status in Myanmar" [online].http://unpan1.un.org/intradoc/groups/public/documents/u n-dpadm/unpano42226.pdf(diakses 25 Maret 2016).

International Telecommunication Union, 2008. "Committed to Connecting The World" [online].http://www.itu.int/newsroom/features/ict(diakses 27 Februari 2016).

ISOC, 2015. "Unleashing the Potential of the Internet for ASEAN Economies" [online].http://www.internetsociety.org/sites/default/files/ASEAN_I SOC_Digital_Economy_Report_Full_o.pdf (diakses 26 Maret 2016).

Kwang, Kevin, 2012. "Asian Countries Show Stark Digital Divide," 5 April [online]. http://www.zdnet.com/article/asian-countries-showstark-digital-divide/ (diakses 11 Maret 2016).

Tech in Asia, 2016. "The Cost of Mobile Data in Southeast Asia" 20 Januari [online]. https://www.techinasia.com/cost-mobile-datasoutheast-asia-infographic(diakses 1 April 2016).

The Internet Society, 2015. "Global Internet Report 2015: Mobile Evolution and Development of the Internet" [online]. http://www.internetsociety.org/globalinternetreport/2015/section/o (diakses 1 April 2016). 